\title{
Effect of Guided Inquiry Learning Model Assisted by Student Worksheets on Student Process Skills in Biochemistry Course
}

\author{
G Gustina* \\ STKIP Pembangunan Indonesia \\ Makassar, Indonesia \\ gustina13082014@gmail.com
}

\author{
Eka Fitriana Hamsyah \\ STKIP Pembangunan Indonesia \\ Makassar, Indonesia \\ ekhafitriana89@yahoo.co.id
}

\author{
Fandi Ahmad \\ STKIP Pembangunan Indonesia \\ Makassar, Indonesia \\ fandi.chem@gmail.com
}

\begin{abstract}
This research is an experimental research which aims to determine the effect of the guided inquiry learning model assisted by student worksheets on the process skills of students in a Biochemistry course. The research design was one group pretest-posttest design. The instrument used to measure students' process skills was a process skills test consisting of biochemical questions. This research was conducted using a guided inquiry learning model assisted by student worksheets. The guided inquiry model consists of orientation, presenting problems, formulating hypotheses, collecting data, testing hypotheses, and drawing conclusions. The data analysis showed a normal sample distribution. The Paired Sample TTest showd a significance value of $p=0.000$ and $\alpha<0.050$ was obtained. This shows that that there is an influence of the LKM-assisted inquiry learning model on student process skills in the STKIP-PI biochemistry course.
\end{abstract}

Keywords—guided inquiry, process skills

\section{INTRODUCTION}

The inquiry learning model is a part of the constructivist approach which is an important part of educational innovation. One of the goals of inquiry learning is to form intellectual abilities or thinking skills so that they can help students build their learning abilities.

Guided inquiry learning has five stages: presenting questions or problems, making hypotheses, designing experiments, collecting and analysing data, and making conclusions [1].

The lab has an important role to promote the activity of learners in learning and strengthen the understanding of concepts in theory. Learners need an activity guidance that for practical activities. For this purpose, worksheets are type of printed material that is often used by educators in the learning process in the laboratory [2].

An important aspect of learning is the students' process skills. Students with good process skills are students who can construct their knowledge. Process skills can be used to find concepts, principles, or theories to develop pre-existing concepts or to refute an invention.

In science learning, there are two groups of process skills, basic science process skills and integrated process skills. Basic skills includes observing, classifying, inferring, measuring, communicating, and predicting, while integrated process skills includes identifying variables, constructing hypotheses, tabulating and graphing data, defining variables, designing investigations, and experimenting [3].

Based on previous observations it can be seen that students' understanding of biochemistry courses is still lacking. This can be seen from the results of midterm and final semester exams which are still low. Therefore, the lecturer must think about the learning model in the classroom so that students can know, understand, and apply it in everyday life.

Based on the description above, the guided inquiry learning model with student worksheets is expected to affect the process skills of STKIP-PI students. The objective of this research is to determine the effect of guided inquiry learning models assisted by student worksheets on student process skills in biochemistry course.

\section{METHODS}

This research was conducted at the STKIP-PI Makassar. It is an experimental research using this research design, the one-group pre-test - post-test design. The population in this study were all STKIP-PI students who took biochemistry courses. The sample used was class $C$ students consisting of 32 samples. The type of instrument used in this study was a test instrument in the form of questions concerning indicators of process skills. Process skills questions are validated before being given to the pre-test. The data were collected by giving process skills questions on the pre-test and post-test. Data management was carried out using descriptive data analysis and inferential data analysis. The descriptive analysis consists of minimum value, maximum value, mean and standard deviation. The effective analysis consists of a normality test and a homogeneity test. After the data is declared normal and homogeneous, it is followed by hypothesis testing.

Hypothesis testing on students' process skills was carried out using SPSS 17 with the Paired-Sample T-Test. There is no significant effect of using the Guided Inquiry learning model assisted by Student Worksheets on Process Skills $\left(\mathrm{H}_{0}\right)$ and There is a significant effect of using the Guided Inquiry learning model assisted by Student Worksheets on process skills $\left(\mathrm{H}_{1}\right)$ with the test criteria: accept $\mathrm{H} 0$ if $\operatorname{sig}(\mathrm{p})>\alpha=$ 0.05 . 


\section{RESULTS AND DISCUSSION}

Process skills were measured using a metacognitive awareness test which includes aspects of process skills in the form of observing, counting, drawing, classifying, predicting, and concluding. Based on the process skills instrument, statistical data were obtained as shown in Table I.

TABLE I. ANALYSIS DESCRIPTION PROCESS SKILLS

\begin{tabular}{|l|l|l|l|l|l|}
\hline Statistics & $\begin{array}{c}\text { Sample } \\
\text { Size }\end{array}$ & Minimum & $\begin{array}{c}\text { Value } \\
\text { Maximum } \\
\text { Value }\end{array}$ & Mean & $\begin{array}{c}\text { Standard } \\
\text { deviation } \\
\text { (SD) }\end{array}$ \\
\hline Pretest & 32 & 40 & 75 & 57.81 & 9.5 \\
\hline posttest & 32 & 55 & 90 & 73.75 & 8.42 \\
\hline
\end{tabular}

Furthermore, inferential analysis is carried out through the normality test (to find out whether the data we get is normally distributed or not), homogeneity test (carried out to find out whether the data we get comes from homogeneous data or not), as seen in table 2 , and table 3 below

TABLE II. NORMALITY TEST

\begin{tabular}{|l|l|l|}
\hline Data Source & Sig & Ket \\
\hline Pretest & 0.11 & Normal \\
\hline Posttest & 0.103 & Normal \\
* Significance level 0.05 &
\end{tabular}

The normality test uses SPSS for windows version 17.0 One-Sample Kolmogorov-Smirnov with the test criteria if the significance $>0.05$ then the data is normally distributed, whereas if the significance $<0.05$ then the data is not normally distributed.

TABLE III. HOMOGENEITY

\begin{tabular}{|l|l|l|}
\hline Test ofTest & Sig & Ket \\
\hline Levene & 0.125 & Homogeneous \\
\hline
\end{tabular}

* Significance level of 0.05

Test using SPSS for windows version 17.0 Homogeneity Levene with the test criteria if the significance> 0.05 then the data obtained is homogeneous and if the significance value $<0.05$, the data obtained is not homogeneous.

Based on the analysis prerequisite testing, it was stated that the data was normal and homogeneous, then hypothesis testing was carried out using the SPSS 17 Paired Samples Test, the significance value was $0.0001>\alpha=0.050$.

The result shows that there is an effect of guided inquiry learning models on processing skills in biochemistry courses in STKIP-PI students. Activities in guided inquiry learning place students to seek and discover for themselves, meaning that students as learning subjects and teachers as facilitators, and this learning model helps students develop their intellectual abilities as part of a mental process, which means that students are not required to only master the material but how to develop their potential.

This is in line with [1] which shows an influence of guided inquiry models assisted by simple practical tools with experimental methods on students' creative thinking abilities, and [4] the results of this study indicated that the guided inquiry science learning materials were valid, practical, and effective to enhance the science literacy skills of prospective MI teachers.

The guided inquiry learning model assisted by student worksheets that are applied in the online learning process can improve students' ability to express answers to problems through data interpretation until a conclusion is obtained. The guided inquiry model not only requires students to be able to carry out the investigation process independently but also requires students to be able to understand the implications of an experimental result as outlined in the form of student worksheets.

LKM is expected to increase understanding of concepts, attract interest in learning, and help students be actively involved in the learning process. Worksheets are arranged systematically with an emphasis on certain aspects so that the skills of students in the learning process can be obtained [5].

The application of guided inquiry learning models with the help of student worksheets can stimulate student process skills because this LKM contains questions that are done by students at each meeting, this is in line with [6] which states that the use of student worksheets can increase student activity.

Science process skills are grouped into various skills, including basic scientific process skills which include the skills to observe, classify, predict, measure, conclude, and communicate. The guided inquiry learning process assisted with student worksheets that are applied guides students to carry out various activities to develop science process skills that support social life according to the steps in the guided inquiry learning model as follows: Orientation, Presenting Problems, Formulating Hypotheses, Collecting data, testing hypothesis, and draw conclusions.

Research that supports the results of this study is Research [7] which states that the application of guided inquiry learning models equipped with worksheets can improve science process skills and student achievement. The aspects of process skills in this study are observation, counting, drawing (analyzing with pictures), classifying, predicting, and concluding. By measuring student's process skills in microbiology lectures, students get closer to the scientific process. Process skills also involve cognitive and intellectual skills. Not only that, but it also involves social skills that interact in communicating between students and students, between students and lecturers [8]

Process skills indicators applied in this study are indicators of observing, counting, drawing, classifying, predicting, and concluding.

\section{CONCLUSION}

Based on the results of research that has been conducted on the guided inquiry learning model assisted by student worksheets on the process skills in biochemistry course, it can be concluded that there is an effect of the guided inquiry learning model assisted by student worksheets on Process Skills in the biochemistry course. Student process skills still have to be developed and improved. The process of improving process skills cannot be done in a short time, so 
that lecturers must actively develop and improve student process skills by using guided inquiry learning models or other learning models that are able to measure student process skills.

\section{ACKNOWLEDGMENT}

This research can be completed properly because of the help of various parties, therefore on this occasion the author would like to thank the Research and Technology Agency of the National Agency for Research and Technology, the Chairperson of STKIP Pembangunan Indonesia, the Head of the Institute for Research and Community Service (LP2M), and all students who helped carry out the research.

\section{REFERENCES}

[1] M. Zaky, "Guided inquiry learning model, simple practicum tool, creative thinking skills," Berk. Ilm. Pendidik. Fis., vol. 7, no. 3, p. 205, 2019.

[2] S. F. Aldilha Yudha, Yulkifli, and Yohandri, "Validity of student worksheet based on guided inquiry learning model assisted by digital practicum tool," J. Phys. Conf. Ser., vol. 1185, no. 1, 2019.
[3] E. S. Safaah, M. Muslim, and W. Liliawati, "Teaching science process skills by using the 5-stage learning cycle in junior high school," J. Phys. Conf. Ser., vol. 895, no. 1, 2017.

[4] M. I. S. Putra, W. Widodo, and B. Jatmiko, "The development of guided inquiry science learning materials to improve science literacy skill of prospective mi teachers," J. Pendidik. IPA Indones., vol. 5, no. 1, pp. 83-93, 2016.

[5] H. Kardena and M. Mawardi, "development of guided inquiry-based student worksheet for first college student," Int. J. Sci. Res. Publ., vol. 10 , no. 10 , pp. 375-379, 2020.

[6] M. Febriani, "pemanfaatan lembar kerja mahasiswa untuk meningkatkan keaktifan mahasiswa: studi penerapan lesson study pada mata kuliah buku teks pelajaran bahasa indonesia," J. Pendidik. Bhs. dan Sastra, vol. 16, no. 2, p. 203, 2016.

[7] D. Kurniawati, M. Masykuri, and S. Saputro, "penerapan model pembelajaran inkuiri terbimbing dilengkapi lks untuk meningkatkan keterampilan proses sains dan prestasi belajar pada materi pokok hukum dasar kimia siswa kelas x MIA 4 SMA N 1 karanganyar tahun pelajaran 2014/2015," J. Pendidik. Kim. Univ. Sebel. Maret, vol. 5, no. 1, pp. 88-95, 2016.

[8] F. Harahap, "Penyusunan Instrumen Keterampilan Proses Sains Berbasis Inkuri Kontekstual pada Perkuliahan Mikrobiologi The Development of Science Process Skill Instruments Based Contextual Inquiryin Microbiology Lectures," vol. 15, pp. 627-634, 2010. 